\title{
多自由度アクチュエータ* \\ Actuator with Multi Degrees of Freedom
}

\section{矢野智昭** \\ Tomoaki YANO}

Key words actuator, multi degrees of freedom, energy saving, motor, spherical

\section{1. 緒}

言

工作機械をはじめとする多くの機械が多軸化, 多自由度 化し，それらの装置に使用されるアクチュエータの個数が 増加している，従来のアクチュエータの多くは回転もしく は直線運動の 1 自由度である。したがって, 装置の自由度 数と同じ個数のアクチュエータが必要になる。

1 台で多自由度の動きを実現する多自由度アクチュエー 夕が実用化すれば, 必要なアクチュエー夕の個数が減少す る。多自由度アクチュエータを組み込んだ装置は，1自由 度のアクチュエータで構成した装置と比較して機構が単純 になる。したがって, 装置が小型・軽量化でき, 制御も簡 単・高速化できる. 多数のアクチュエータの調整や組み付 け誤差の蓄積も軽減される. アクチュエータの個数軽減に よる省エネルギー効果ならびに装置の設置場所であるクリ ーンルームや恒温室の容積减少による省エネルギー効果が 期待できる

電気学会では 2002 年 4 月に多次元ドライブシステム調 查専門委員会を立ち上げ, 多自由度アクチュエータの研究 動向, 周辺要素技術, 応用分野の調查研究を行ってき た ${ }^{1 \sim 3)}$ 。ここでは, 電気学会の調査結果をふまえ, 多自由 度アクチュエータの応用分野および実用化に向けた課題に ついて解説する。

\section{2. 多自由度アクチュエータの応用分野}

\section{1 産業・民生応用}

2.1 .1 平面モー夕

2 自由度を 1 台のモータで駆動するサーフェスモー夕， プレーンモータと呼称されるモータは 1970 年代に大型の

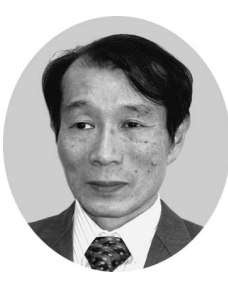

*原稿受付 平成 23 年 6 月 20 日

独立行政法人産業技術総合研究所（茨城県つく ば市並木 1-2-1

矢野智昭

1979 年神戸大学大学院修士課程修了. 同年通産 省工業技術院機械技術研究所入所. フライホイ 一ル車用変速機, 自動縫製用腕機構, 壁面歩行 ロボット, 高精度三次元座標計測装置, 多自由 度アクチュエータの研究に従事.
ペンプロッタ用として米国で実用化された。これはステッ ピングモータ方式であり, その後もレーザ変位計による精 密位置決め制御を取り入れたサーフェスモー夕が半導体や 平面表示器の薄膜プロセス用高精度位置決め機器に国内外 で実用化されている.

図 1 に住友重機械工業株式会社の冨田らが試作したサ ーフェスエンコーダ一体型 5 自由度ステージの構造を示 す. ステージ可動部は約 $400 \mathrm{~mm} \times 400 \mathrm{~mm}$ のアルミ平板 による 1 段構造である. ステージ可動部下面に永久磁石 が，ステージベースにコイルが配置してありリニアモータ を構成している.1つの X モータと 2 つの Y モータが $\mathrm{T}$ 字型に配置してあり, 推力を発生させることで, XY $\theta_{z}$ 駆 動を可能にしている.リニアモータのギャップは $1 \mathrm{~mm}$ で あり, 最大推力は $\mathrm{X}$ モータ $27 \mathrm{~N}, \mathrm{Y}$ モータ $19 \mathrm{~N}$ である. ステージ可動部はエアベアリングと圧電素子を直列接続し た 3 本の支持機構で支えられており，ステージベースに対 し約 $10 \mu \mathrm{m}$ 浮上し, 非接触で支持されている。 また, 圧 電素子の伸縮により, ステージ可動部の Z 変位 $34 \mathrm{~mm}$, $\theta_{\mathrm{x}}$ 変位 $18 \operatorname{arcsec}, \theta_{\mathrm{y}}$ 変位 $19 \operatorname{arcsec}$ を発生させることがで きる. $x y$ 方向 $50 \mathrm{~nm}, \mathrm{xy}$ 軸周り $0.15 \operatorname{arcsec}, \quad z$ 軸周り 0.5

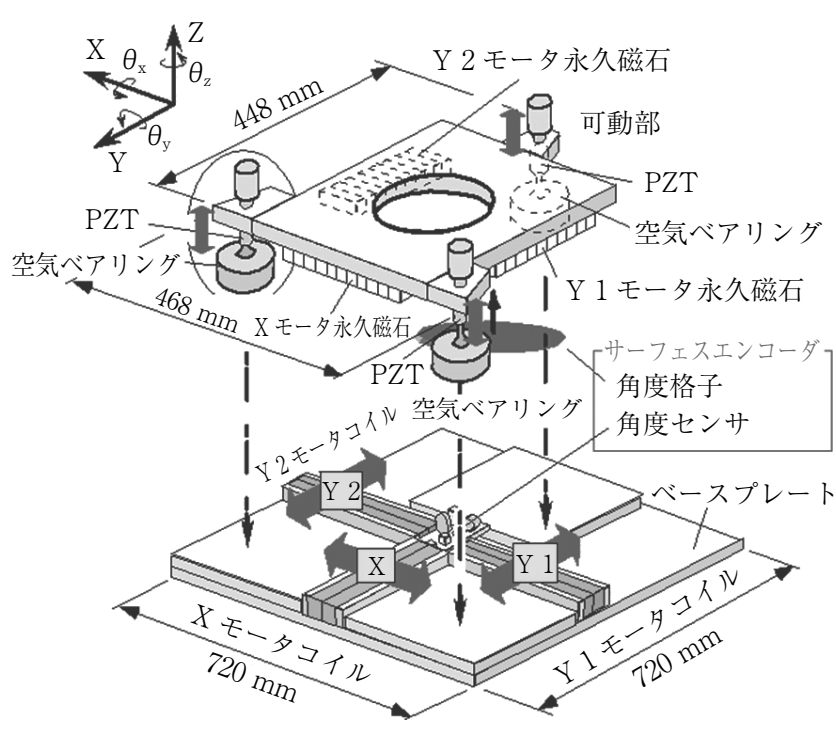

図 1 サーフェスエンコーダ一体型 5 自由度ステージの構造 


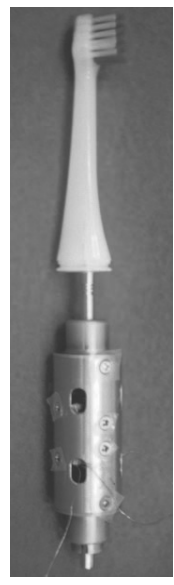

(a) 本体

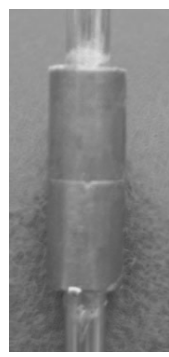

（b）可動子

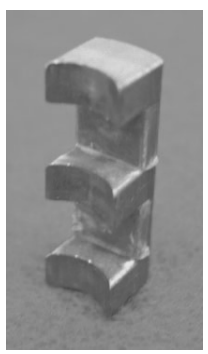

(c) $\mathrm{E}$ 型固定子

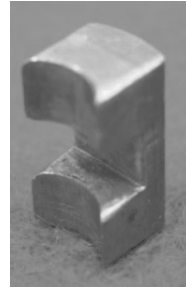

（d） C 型固定子

図 2 音波歯ブラシの構造

$\operatorname{arcsec}$ の位置決め精度を達成している ${ }^{4)}$.

東北大学の小野は走査型プローブ顕微鏡で原子や分子を 拾い上げ, アクチュエータで大きく動かした後, 強い電界 で原子をとばして，質量分析するシステムにおいてモノリ リックPZTを用いたXYZ ステージを試作している ${ }^{5)}$. 豊 田工業大学の古谷は 2 力所の摩擦力と 2 個の伸縮型ピエゾ アクチュエータの組み合わせにより $\mathrm{xy} \theta$ の三自由度の微 小移動を実現したアザラシ型位置決め機構を開発した。本 移動機構をパラレル機構微動ステージと組み合わせ, ナノ メータからミリメートルオーダまでの領域で物体を操作 観察するシステムの開発を目指している ${ }^{6}$.

\subsection{2 円筒モータ}

大阪大学の平田らは図 2 に示す音波歯ブラシ用 2 自由 度振動駆動円筒型モー夕を開発した ${ }^{77}$ 。このモータは上部 と下部で円周方向の磁界が反転するように磁石を配置した 可動子, 可動子を縦方向に振動駆動する E 型固定子, お よび可動子を軸周りに回転振動駆動するC 型固定子で構 成され，軸方向と回転方向の往復運動を同時に行うことが できる，希土類磁石を使用し，ギャップ長は $0.3 \mathrm{~mm}$ であ る. 軸方向と回転の同時駆動が可能である. 軸方向動作は 入力電圧 $2.2 \mathrm{~V}$ で共振周波数 $265 \mathrm{~Hz}$, 振幅 $0.7 \mathrm{~mm}$, 回転 方向は入力電圧 $4.5 \mathrm{~V}$ で共振周波数 $370 \mathrm{~Hz}, \pm 0.8 \mathrm{deg}$ であ り，2 軸ねじり動作を実現した． 2 軸複合動作により歯垢 除去効果が高まることを人工歯垢により評価している.

\subsection{3 球面モー夕}

産総研の矢野らは, 図 3 に示す全自動基板検查装置用 ウェハ三次元駆動装置用球面ステッピングモータを試作し た. 円弧状のステッピングモータを 2 台入れ子状にし，そ の内側に回転ステッピングモータを配置して 3 自由度を実 現している，大きさは $160 \times 218 \times 207 \mathrm{~mm}, 4.3 \mathrm{~kg}$ で，内側 が無限回転, 真ん中と外側がそれぞれ $\pm 45 \mathrm{deg}$ の可動範 囲を有している。歯のピッチがそれぞれ $4 \mathrm{deg}, 3 \mathrm{deg}, 3$ $\operatorname{deg}$ で 1 周期を 512 分割するマイクロステップ駆動を行っ ている。 ギャップ長 $0.1 \mathrm{~mm}$ で位置決め精度はそれぞれ

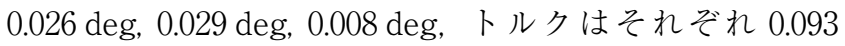

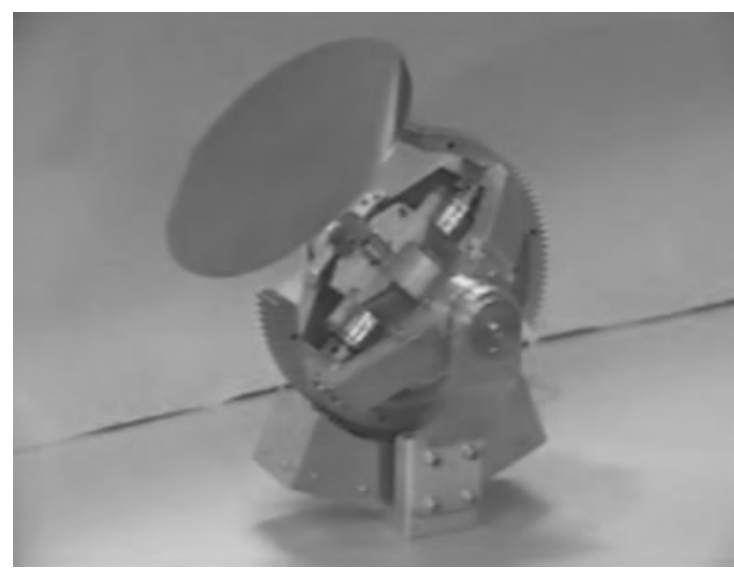

図 3 ウェハ全自動検查装置のウェハ操作部

Nm, $0.38 \mathrm{Nm}, 2.06 \mathrm{Nm}$ である ${ }^{8}$.

Georgia 工科大学の K. M. Lee らは高速で回転するモー 夕の回転軸方向をオープンループで制御する球面リラクタ ンスモータを試作した，ステー夕に 20 極の電磁石，ロー 夕に 16 極の永久磁石をそれぞれ 2 段に配置している。 ータ半径は $76.2 \mathrm{~mm}$ で, 自動車の車輪をダイレクトに駆 動でき, 特別な機構を付加することなくステアリングを切 ることができると主張している99.

\section{2 ロボット応用}

2.2.1 眼の駆動

産総研の矢野らはロボットの眼に使用する CCD カメラ 駆動小型球面モー夕を開発し, 位置決め精度 $0.03 \mathrm{deg}$ を 実現した ${ }^{10)}$. 現在のヒューマノイドロボットの CCD カメ ラは固定のため視野角が狭い，パチンコ玉程度の大きさの $\mathrm{CCD}$ カメラ駆動用多自由度モー夕の実現が切望されてい る.

\section{2 .2 関節の駆動}

東大の樋口らは図 4 に示寸非接触 5 自由度手首機構を 提案した。本手首機構は並進 $\pm 0.6 \mathrm{~mm}$, 回転 $\pm 0.7 \mathrm{deg}$, 位置決め精度はギャップセンサの分解能である $0.001 \mathrm{~mm}$, 出力 $100 \mathrm{Nm}$ で, 力覚センサ機能と可変コンプライアンス 機能を有し, 当時困難とされたぺグの挿入を行うことがで きた ${ }^{11}$.

Aahen 工科大学の K. Kahlen らは, ステータに 96 個の 電磁石, ロー夕に 48 組の永久磁石を配置し, 各電磁石に 専用 DSP ボードを割り当てた球面ステッピングモー夕を 試作した. DSP ボードが, あらかじめ実験で求めた電磁 石と永久磁石の位置と吸引力のテーブルを参照して各電磁 石流す電流值を計算する。 ロー夕直径 $275 \mathrm{~mm}$, 可動範囲 $\pm 60 \mathrm{deg}$ ，回転速度 $115 \mathrm{rpm}$ で出力トルク $40 \mathrm{Nm}$ である. ロータはエアで支持している ${ }^{12)}$.

産総研の矢野らは, 図 5 に示す多極球面同期モー夕を 試作した。ロー夕には 260 個の希土類磁石をX 軸㧍よび $\mathrm{Y}$ 軸を中心とする同心円上に, 半径方向に $\mathrm{N}$ 極と $\mathrm{S}$ 極が 交互に現れるように貼っている。ステー夕にはX 軸回り 


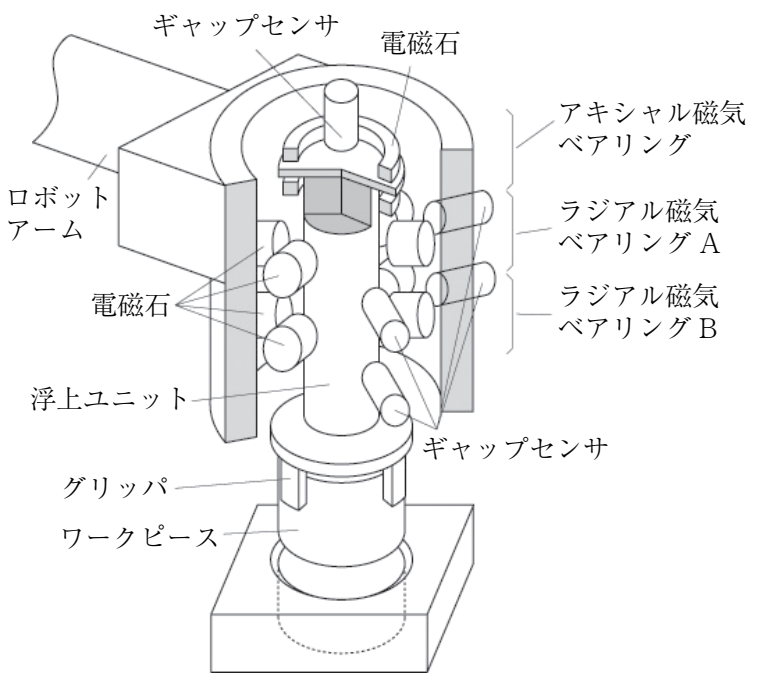

図 45 自由度手首機構 MEISTER

の回転力を発生するアマチュア巻線 $\mathrm{A}, \mathrm{A}^{\prime}$ 拉よび $\mathrm{Y}$ 軸周り の回転力を発生させるアマチュア巻線 B, B'をそれぞれ 90 deg 回転した位置に配置している。モモタ寸法 $265 \mathrm{~mm}$ 立 方, $8.6 \mathrm{~kg}$, ロー夕直径 $130 \mathrm{~mm}$, 界磁電流 $1.62 \mathrm{~A}$, エン コーダ信号フィードバックにより可動範囲 $\pm 45 \mathrm{deg}$, 最 高速度 $90 \mathrm{deg} / \mathrm{s}$, 位置決め精度 $0.00348 \mathrm{deg}, 45 \mathrm{deg}$ 方向の 出力トルク $0.69 \mathrm{Nm}$ である ${ }^{13)}$.

東京農工大の遠山らは超音波モー夕の保持・駆動卜ルク の大きさを生かしてロボットの関節駆動用多自由度モー夕 を開発し，実用化を目指している。球体のロー夕を円環状 の振動子で 3 方向から挟み込む構造で, 複数のステー夕に 同時に進行波を発生させるとロー夕は各々の進行波で発生 した回転べクトルの合成方向に回転する。これにより，3 軸回りの回転を実現している。質量は $175 \mathrm{~g}$, 可動範囲は $\mathrm{X}$ 軸回り $130 \mathrm{deg}, \mathrm{Y}$ 軸回り $120 \mathrm{deg}, Z$ 軸回り $360 \mathrm{deg}, 120$ $\mathrm{Vp}-\mathrm{p}$, 出力トルクは X 軸 $0.08 \mathrm{Nm}, \mathrm{Y}$ 軸 $0.058 \mathrm{Nm}, Z$ 軸 $0.04 \mathrm{Nm}$ である ${ }^{14)}$.

\section{3 センサ応用}

産総研の矢野らは非接触三次元座標計測装置に用いるレ ーザ追尾距離測定装置のレーザ光反射ミラーの球面駆動に 球面モー夕を採用した。非接触三次元測定は，4 台のレー ザ追尾距離測定システムで計測した対象物までの距離情報 を用いて対象物の三次元座標を求める。 標を 12 力所測定したとする. 得られる距離デー夕は 48 個 であり，これから対象物の 12 力所の座標 (未知数 36 個) およびレーザ追尾座標測定装置の 4 力所の基準座標（未知 数 12 個）が求められる. したがって，4 台のレーザ追尾 距離測定装置を適当に配置して測定を開始できる. 球面モ ー夕を採用することによりレーザ追尾座標測定装置の容積 が1/6になり，アタッシュケースに 4 台収納してフィール ドに運搬し，即座に三次元座標計測を行うことが可能にな った. 球面モー夕は $88 \mathrm{~mm} \times 85 \mathrm{~mm} \times 71 \mathrm{~mm}$ で $0.75 \mathrm{~kg}$, 直径 $8 \mathrm{~mm}$ のミラーを貼った直径 $12.7 \mathrm{~mm}$ の半球を各軸
周りに $\pm 21 \mathrm{deg}$ 傾けることができる，最高速度 $90 \mathrm{deg} / \mathrm{s}$, 位置決め精度は X 軸 $0.00176 \mathrm{deg}, \mathrm{Y}$ 軸 $0.00127 \mathrm{deg}$, 出力 トルクは X 軸 $0.20 \mathrm{Nm}, \mathrm{Y}$ 軸 $0.03 \mathrm{Nm}$ である ${ }^{15)}$.

Darmstadt 大学を中心とするグループは, NASA との 共同開発によりボーイング 747 に搭載し成層圈で観測する 大型赤外線望遠鏡の光軸を 3 方向にトラッキングする球面 モー夕を開発している ${ }^{16)}$.

東北大学の佐々木らは静電駆動型 MEMS 光スキャナに シリコンピエゾ抵抗型回転角センサを組み込んだ高精度光 スキャナの実現を目指している ${ }^{17)}$.

\section{4 医療福祉への応用}

慶應大学の前野, 竹村らは共振振動数の異なる圧電素子 を組み合わせ，ロー夕を 3 軸周りに回転させる小型球面モ 一タを試作し, グリッパの付け根が球面運動する鉗子に応 用した。ロータの直径が $10 \mathrm{~mm}$, 全長 $31.9 \mathrm{~mm}$, 質量 $16.9 \mathrm{~g}$ で 3 軸回りの回転が可能である ${ }^{18)}$.

\section{3. 実用化に向けた課題}

数多くの特長を有し, 実現すればメカトロニクス設計に ブレイクスルーをもたらす多自由度アクチュエータである が, 実用化に向けて課題も多い.

\section{1 設計・解析技術}

多自由度アクチュエータの構造, 自由度, 駆動原理は多 岐にわたり，目的に応じた設計を行うには多自由度アクチ ユエータの体系化が重要である. アクチュエー夕の要求仕 様と構造を決定すれば有限要素法とモーションの連成解析 により実用的な解析結果が得られるようになりつつある。 超音波振動の三次元解析と GA（遺伝的アルゴリズム）に よる球面超音波アクチュエータの最適形状設計例が報告さ れている ${ }^{19}$.

\section{2 支持・案内技術}

1 軸モータのロータは回転軸で保持できるのに対し, 多 自由度アクチュエータのロータを回転中心で保持すること は困難である.ジンバル機構などで支持すると支持点が回 転中心から遠くなり，たわみによる誤差やぶれが生じる． また，モータが大きくなり構造も複雑になる．3 自由度転 がり軸受が試作実験されている ${ }^{20)}$. 球体べアリングでロー 夕表面を支持する方法は，摩擦や芯ぶれの問題がある。磁 気浮上もしくは空気浮上はロータの中心位置を制御する必 要がある。多自由度アクチュエータの駆動コイルがロータ 支持を兼ねられれば理想的である。

\section{3 センサ技術}

多自由度, 特に球面の位置や速度情報のセンシングが課 題である. ジンバル機構の交差部に一軸センサを用いる方 法は支持・案内技術と同じ理由で害用的でない. 球面エン コーダが提案されている ${ }^{21}$. イメージセンサ ${ }^{22}$ やホール素 子を使用した位置センサが試作されているが，実用化には 至っていない，多自由度アクチユエータの駆動コイルの電 圧と電流の関倸からロータの位置拉よび出力トルクが得ら れれば理想的である。 


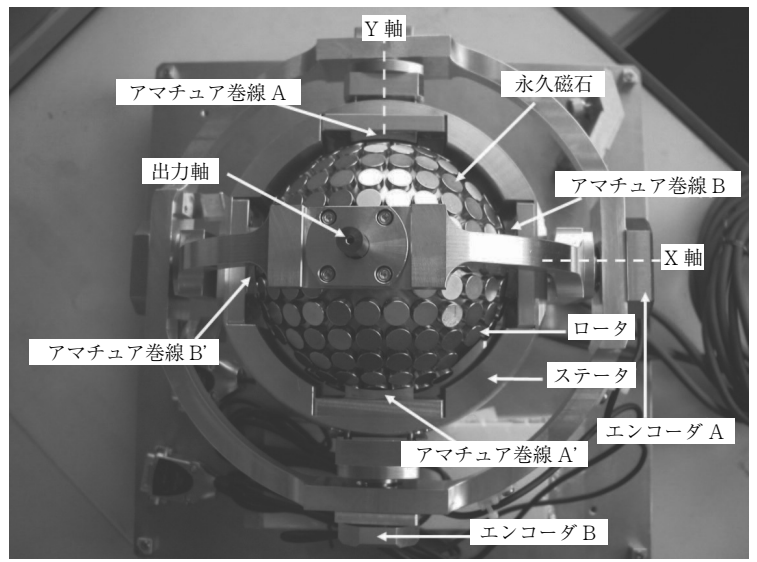

図 5 多極球面同期モー夕

\section{4 駆動・制御技術}

多自由度アクチュエータは動きそのものが最も重要な出 力であり, 高精度の駆動制御を適用する必要がある. しか し, 優れたセンサが現れないと, 高精度の駆動制御は実現 困難である。

\section{5 評価技術}

一軸モー夕に扔いても一定の回転数で回転させる使用方 法は減少しているが, 多自由度アクチュエータではそのよ うな使用方法は皆無になり, 出力を入力で除した効率を評 価基準とするのは適当でない，新しい評価指標が必要であ る. 日本の電力エネルギー消費の $50 \%$ 以上を電磁モー夕 が占めて扮り, 評価指標への省エネルギーの組み込みが久 かせない，

\section{6 減速機技術}

ロボットの肩関節の駆動は 1 軸モータと高減速比の減速 機の組み合わせが一般的である。1 軸モー夕は数百グラム で 1：100 以上の減速比を有する波動減速機と組み合わせ て，70 Nm 以上のトルクを実現している。これに匹敵す る多自由度アクチュエータ用の減速機の開発が必須であ る. 球面減速機のアイデアが提案されている ${ }^{23)}$.

\section{4. 結}

\section{言}

日本は 2020 年までに地球温暖化ガスの排出量を 1990 年 比 $25 \%$ 減とする目標を揭げている。 日本の電力消費の $50 \%$ 以上をモー夕で消費して㧍り，この比率は年々増加 の傾向にある. 経済産業省は 2011 年 1 月 24 日の総合資源 エネルギー調查会第 16 回省エネルギー基準部会に扔いて 三相誘導モータを省エネルギーのトップランナー基準の対 象とした。多自由度アクチュエータの採用によるモー夕個 数の減少は, アクチュエータの省エネルギーに大いに貢献 できる，多自由度アクチュエータの実用化に向けて本体抒 よび周辺技術の開発を加速することが重要である.

\section{参 考 文 献}

1) 多次元ドライブシステム調査専門委員会 : 多次元ドライブシス テムの可能性を探る, 電気学会技術報告, 1029 (2005).
2) 多自由度モー夕とその要素技術調査専門委員会 : 多自由度モー 夕とその要素技術, 電気学会技術報告, 1081 (2007).

3) 多自由度モータのシステム化技術調査専門委員会: 多自由度モ 一タのシステム化技術, 電気学会技術報告, 1140 (2008).

4）出島秀一, 高偉, 清野慧, 冨田良幸: サーフェスエンコーダを 用いた平面モー夕の 5 自由度精密位置決め, 2004 年度精密工学 会春季大会学術講演会講演論文集，（2004） 1141 .

5) T. Ono, Y. Kawai, S. Yoshida, K. Iwami, H. Xu and M. Esashi : Actuator Integrated Microprobes for Advanced Analysis in Nanoscale, Proceedings of the 1st International Symposium on Next-Generation Actuators Leading Breakthroughs, (2006) 21.

6) K. Furutani : AZARASHI (Seal) Mechanism for Meso/Micro/ Nano Manipulators, Proceedings of the 1st International Symposium on Next-Generation Actuators Leading Breakthroughs, (2006) 13.

7) 平田勝弘, 一井義孝, 有川泰史 : 動吸振器一体型リニア振動ア クチュエータ，電気学会論文誌 D, 122, 4 (2002) 346.

8）矢野智昭, 鈴木健生: 球面モー夕の, 基板検査装置への応用可 能性の検討, 電気学会リニアドライブ研究会資料, LD-07, 32 (2007) 1 .

9) K.M. Lee, H. Son and J. Joni : Concept Development and Design of a Spherical Wheel Motor (SWM), Proceedings of the 2005 IEEE International Conference on Robotics and Automation, (2005) 3663.

10) T. Yano and T. Suzuki:Basic Characteristics of the Small Spherical Stepping Motor, Proceedings of 2002 IEEE/RSJ International Conference on Intelligent Robots and Systems, (2002) 1980.

11）樋口俊郎, 津田匡博, 藤原茂喜: 磁力支持方式精密自動組立用 ハンドの開発，日本ロボット学会誌，7, 2 (1989) 136.

12) K. Kahlen and R.W. DeDoncker:Current Regulators for Multiple-phase Permanent Magnet Spherical Machines, Proceedings of IEEE Industrial Application, (2000) 2011.

13）矢野智昭, 久保田義昭, 鹿山透, 鈴木健生 : 2 自由度球面同期 モータの開発，日本 AEM 学会誌， 17, 1 (2009) 29.

14）深谷直樹, 和田博, 菊池保広, 古屋信幸, 遠山茂樹: 超音波乇 ー夕を用いた人工の腕の開発，ライフサポート，12,4(2000) 131.

15）矢野智昭, 高辻利之, 大澤尊光, 鈴木健生, 本村洋一, 板部忠 喜：サブミクロンの測定精度を有する小型 2 軸球面モータ型レ 一ザ追尾距離測定装置の開発，電気学会論文誌 E, 126, 4 (2006) 144.

16) M. Anders, A. Binder and M. Suess : A Spherical Linear Motor as Direct Drive of an Airborne Optical Infrared Telescope, Proceedings of LDIA, (2005) 523.

17) M. Sasaki, M. Tabata, Y. Kanamori and K. Hane: Micromirror Integrated with Rotation Angle Sensor, Proceedings of the 1st International Symposium on Next-Generation Actuators Leading Breakthroughs, (2006) 47.

18) S. Park, K. Takemura and T. Maeno : Development of Multi-DOF Actuator for Surgical Tools, Proceedings of the 32nd International Congress and Exposition on Noise Control Engineering, (2003) 3039.

19）田蔵淳史, 前野隆司：遺伝的アルゴリズムを用いた多自由度超 音波モー夕の設計方法, 日本機械学会第 6 回機素潤滑設計部門 講演会講演論文集，（2006） 275.

20）尾崎浩一, 矢野智昭, 武田稔, 石川雄一：三自由度転がり軸受 の試作，機械技術研究所所報，51，6 (1997) 167.

21) D. Stein, E.R. Scheineman and G.S. Chirikjian: Mathematical Models of Binary Spherical-Motion Encoders, IEEE/ASME Trans. on Mechatronics, 8, 2 (2003) 234.

22）熊谷正朗, R.L. Hollis：マウス用センサを用いた球面および平面 の高分解能運動計測, 日本機械学会ロボティス・メカトロニク 又講演会講演論文集，（2011）2A2-K07.

23）矢野智昭：球面加減速機構の設計, 日本機械学会年次大会講演 論文集, 7 (2009) 247. 